

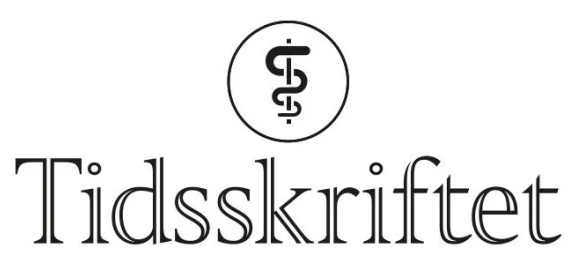

DEN NORSKE LEGEFORENING

\title{
Interaktiv e-helse
}

\author{
MEDISINSK NYTT
}

PER EGIL KUMMERVOLD

Email: per.egil.kummervold@telemed.no

Nasjonalt senter for telemedisin

Troms $\emptyset$

\section{Bruk av Internett til helseformål øker stadig og blir også mer interaktiv. Det vil gi nye utfordringer for helsevesenet.}

Undersøkelsen eHealth Trends omfattet nesten 15 ooo telefonintervjuer i to runder: våren 2005 og høsten 2007. I tillegg til nordmenn ble et representativt utvalg av personer fra Danmark, Portugal, Tyskland, Hellas, Latvia og Polen intervjuet om sin bruk av Internett i forhold til helse $(\underline{1}, \underline{2})$.

Undersøkelsen viste at folk i stadig større grad bruker nettet til helseformål. Andelen av nettbrukerne i de sju landene som hadde hentet helseinformasjon fra nettet, økte fra $42 \%$ i 2005 til 52 \% i 2007. De mest aktive er unge kvinner.

Undersøkelsen viste også at 47 \% av de spurte mente at Internett var en viktig kilde til helseinformasjon. Det er en økning fra 40 \% i 2005. Bruk av andre medier som TV, aviser og radio blir mindre viktig.

Bruken av e-helse blir også mer interaktiv, og brukerne kommuniserer mer direkte med andre brukere, pasienter og helsepersonell. $23 \%$ av de som ble spurt i 2007 hadde brukt nettet på denne måten.

Dette vil gi nye utfordringer for både fastleger og spesialisthelsetjenesten, i og med at brukerne blir mer informert om helsespørsmål og i større grad vil forvente toveiskommunikasjon med helsevesenet over nettet.

\section{LITTERATUR}

1. Andreassen HK, Bujnowska-Fedak MM, Chronaki CE et al. European citizens' use of E-health services: a study of seven countries. BMC Public Health 2007; 7: 53.

2. Kummervold PE, Chronaki CE, Lausen B et al. eHealth trends in Europe 2005-2007: a populationbased survey. J Med Internet Res 2008; 10: e42. www.jmir.org/2008/4/e42 (17.1.2009).

Publisert: 26. februar 2009. Tidsskr Nor Legeforen. DOI:10.4045/tidsskr.09.0139

(C) Tidsskrift for Den norske legeforening 2023. Lastet ned fra tidsskriftet.no 26. april 2023. 
